\title{
EFECUTUL RHIZOBACTERIILOR BENEFICE ASUPRA FORMĂRII SISTEMULUI SIMBIOTIC GLYCINE MAX-BRADYRHIZOBIUM JAPONICUM ÎN FUNCŢIE DE FERTILIZARE ŞI NIVELUL DE UMIDITATE A SOLULUI
}

\author{
Rotaru $V$. \\ Institutul de Genetică, Fiziologie şi Protecţie a Plantelor, Chisinau, Republica Moldova, \\ e-mail:rotaruvlad@yahoo.com
}

\begin{abstract}
A pot experiment under controlled soil moisture conditions was accomplished with the aim to assess the effect of rhizobacteria application Bradyrhizobium japonicum alone or in conjuction with Pseudomonas putida strain on symbiotic system development of soybean in relation to phosphorus and manure fertilization under temporary drought conditions. Mineral and organic fertilizers were applied during filling pots with soil. A half of plants were subjected to moderate drought for 12 days at flowering stage. The experimental results showed that number of nodules increased after rhizobacteria application under mineral as well as under organic fertilization irrespective of soil moisture levels. The highest effect of rhizobacteria was registered in plants under normal irrigation conditions. Experimental data find out that combined application of two rhizobacteria strains displayed synergic effect on nodules development. Thus, the results suggested that application of $B$. japonicum and Pseudomonas putida strains as biofertilizer contributed to enhance tolerance of soybean plants and promote nodules development under water limited conditions.
\end{abstract}

Key words: manure, nodules, phosphorus, rhizobacteria, soil moisture, soybean

\section{Introducere}

Disbalnasul nutritiv cu fosfor (Andrieş, 2011) şi seceta sunt factorii abiotici ce condiţionează pierderi considerabile ale productivităţii plantelor de cultură în Republica Moldova. În situaţii nefavorabile de mediu utilizarea microorganismelor rizosferice este una din strategiile de adaptare a plantelor agricole la factorii adverşi de mediu (Niu et al., 2018; Ojuederie et al., 2019). Rizobacteriile benefice îndeplinesc un spectru larg de funcţii biologice şi au impact considerabil asupra productivităţii plantelor atât în condiţii optime de umiditate cât şi la secetă (Franzini et al., 2013; Zaidi et al., 2005). Însă mecanismele ce conferă toleranţă mai bună a plantelor la factorii adverşi la utilizarea rizobacteriilor au fost studiate, de regulă, la planta gazdă (Egamberdieva et al., 2009) şi puţin s-a atras atenţia dezvoltării aparatului simbiotic la aplicarea rizobacteriilor în condiţii adverse de mediu. Conform unor cercetări, creşterea şi dezvoltarea plantelor agricole, în mod special formarea nodozităţilor la leguminoase, este afectată considerabil atât de insuficienţa de fosfor (Andries, 2011), cât şi de insuficienta de umiditate din sol (Egamberdieva et al., 2017). Despre efectul sinergetic a unor specii de microorganisme asupra creşterii plantelor s-a raportat în literatura de specialitate (Hungria et al., 2015). De exemplu, co-inocularea la plantele de salata verde cu tulpina Pseudomonas mendocina Palleroni și ciupercile (Glomus intraradices ori Glomus mosseae) a majorat semnificativ creșterea rădăcinilor, a contribuit la acumularea prolinei, la majorarea activităţii nitratreductazei în frunze în condiţii moderate și severe de secetă (Alguacil et al., 2009). Kunert K. şi cercetătorii (2016) în baza investigaţiilor au tras concluzia că formarea nodozităţilor la leguminoase este sever marcată de deficitul de umiditate din sol. Analiza literaturii de specialitate a scos în evidenţă faptul că efectul aplicării rizobacteriilor asupra formării sistemului simbiotic la leguminoase s-a examinat, de obicei, in condiţii nefavorabile a unui singur factor abiotic (Hungria et al., 2015), însă sunt puţine studii care au examinat influenţa utilizării integrale a microorganismelor la acţiunea combinată a doi sau mai mulţi factori ecologici nefavorabili. 
Scopul cercetărilor a constat în evaluarea efectului aplicării tulpinilor de rizobacterii Bradyrhizobium japonicum separat sau în combinare cu tulpina de rizobacterii Pseudomonas putida asupra formării nodozităţilor la plantele de soia în dependenţă de fertilizarea minerală sau organică în condiţii limitate de umiditate.

\section{Materiale şi metode}

Pentru realizarea sarcinii preconizate s-a montat o experienţă în vase în complexul de vegetaţie al IGFPP. În experienţe s-a folosit solul cernoziom carbonatic cu conţinut scăzut de fosfaţi mobili, care a fost amestecat cu nisip (3:1). Fosforul în doză de $100 \mathrm{mg} / \mathrm{kg}$ sol s-a administrat în sol înainte de umplerea vaselor cu sol conform schemei experimentale (Tabelul 1). Cantitatea de gunoi de grajd administrată în sol a constituit $200 \mathrm{~g} / \mathrm{vas}$. Aplicarea microorganismelor rizosferice s-a efectuat prin tratarea seminţelor de soia (soiul Horboveanca) cu suspensia bacteriilor Bradyrhizobium japonicum (BJ) înainte de semănat. Suspensia de rizobacterii Pseudomonas putida (PP) $s$-a administrat în sol până la semănat. Seceta temporară (35\% CTA) a fost instalată în faza de înflorire a plantelor pe o perioadă de 12 zile. Toate variantele conform schemei experienţei s-au montat în 8 repetări. Înainte de montarea experienţelor s-a determinat conţinutul de fosfor şi azot total, al fosfaţilor mobili în sol, capacitatea totală de reţinere a apei în sol (CTA), pH solului, umiditatea solului. În faza coacerii boabelor de soia s-a evaluat efectul interacţiunii bacteriilor rizosferice asupra productivităţii de seminţe a plantelor cultivate pe solul asigurat suboptimal cu fosfor în condiţii de secetă moderată. Cantitatea de nodozităţi formate la plantele de soia s-a estimat la sfârşitul perioadei de secetă temporară.

\section{Rezultate şi discuţii}

Rizobacteriile manifestă potenţial de a induce toleranţa plantelor la factorii de stres abiotic. În prezent nu sunt elucidate definitiv modificările fiziologice şi metabolice care determină rezistenta sporită a plantelor agricole la utilizarea microorganismelor rizosferice (Egamberdieva et al., 2017). Actualmente se acordă o deosebită atenţie promovării agriculturii ecologice atât pe scară internaţională cât şi naţională. Agricultura ecologică prevede aplicarea biotehnologiilor care au menirea să stimuleze productivitatea plantelor pe de o parte, iar pe de alta - aceste tehnologii trebuie să aibă impact minim asupra mediului.

Tabelul 1. Influența rizobacteriilor asupra formării nodozităţilor la soia în funcţie de fertilizarea minerală or organică în condiţii de secetă temporară, buc/2 plante

\begin{tabular}{|l|l|l|l|l|l|}
\hline Variante & Nodozități & \pm SE & Variante & Nodozități & \pm SE \\
\hline P0+BJ,35\%CTA & 4,5 & 1,32 & P100+BJ,35\%CTA & 29,7 & 2,96 \\
\hline P0+BJ+PP,35\%CTA & 8,3 & 0,25 & P100+BJ+PP,35\%CTA & 38,0 & 1,73 \\
\hline P0+BJ,70\%CTA & 13,8 & 1,65 & P100+BJ,70\%CTA & 50,0 & 4,36 \\
\hline P0+BJ+PP,70\%CTA & 23,3 & 3,86 & P100+BJ+PP,70\%CTA & 71,0 & 14,57 \\
\hline Gunoi+BJ35\% CTA & 52,5 & 3,57 & Gunoi+BJ,70\%CTA & 75,3 & 13,50 \\
\hline Gunoi+BJ+PP,35\%CTA & 50,0 & 1,87 & Gunoi+BJ+PP,70\%CTA & 79,5 & 4,06 \\
\hline
\end{tabular}

PO-sol nefertilizat, BJ-Bradyrhizobium japonicum, PP-Pseudomonas putida, P100- soil fertilizat cu $100 \mathrm{mg} \mathrm{P} / \mathrm{kg}$ sol.

Un rol important în promovarea agriculturii sustenabile îl are cultivarea plantelor leguminoase. Cultivarea soii are semnificație nu numai agronomică, economică, dar joacă rol 
principal in asigurarea plantelor cu azot şi contribuie la îmbunătăţirea fertilității solului (Nehra and Choudhary, 2015). Ea are o capacitate deosebita de a asimila azotul din atmosfera pe cale biologică. Pentru formarea productivitaii de 3 tone de boabe soia consumă cca $300 \mathrm{~kg}$ de azot. Formarea sistemului simbiotic Glycine max-Bradyrhizobium japonicum este sub controlul factorilor abiotici, îndeosebi ea depinde de tipul de fertilizare si nivelul de umiditate din sol.

Rezultatele experimentale au demonstrat că formarea sistemului simbiotic la plantele de soia a fost afectat considerabil de tipul fertilizării si de regimul de umiditate din sol (Tabelul 1). E necesar de menţionat că seceta a redus substanţial numărul nodozităţilor pe ambele fonduri de fertilizare. Experimental s-a stabilit că plantele au răspuns diferit la nivel de formare a nodozităţilor la aplicarea tulpinilor bacteriene, în funcţie de umiditatea solului. Deficitul de umiditate a marcat esenţial formarea nodozităţilor la plantele de soia, mai ales pe solul cu insuficienţă de fosfor (varianta P0 - fără fertilizare). Cele mai mici cantităţi de nodozităţi s-au depistat la plantele cultivate la insuficienţa de fosfor combinat cu deficit de umiditate. Folosirea combinată a rizobacteriilor B. japonicum şi Pseudomonas putida a condus la majorarea numărului de nodozității însă impactul pozitiv al biofertilizatorilor s-a evidenţiat destul de pronunţat în condiții optime de umiditate a solului. Influenţe pozitive a rizobacteriilor asupra nodozităţilor s-au stabilit şi în alte studii la specia cicer arietinum L. (Messele et al., 2012). Utilizarea lor combinată pe solul cu administrarea îngrășămintelor minerale cu fosfor a manifestat efect sinergic asupra cantităţii de nodozităţi însă tulpinile bacteriene n-au marcat considerabil numărul de nodozități pe fondalul aplicării gunoiului de grajd comparativ cu aplicarea separată a bacteriilor Bradyrhizobium japonicum. De asemenea, Polonenko D.R. şi colaboratorii (1987) au menţionat faptul că co-inocularea soii cu Pseudomonas sp. (Pseudomonas fluorecens şi Pseudomonas putida) împreună cu bacteriile $B$. japonicum a sporit numărul de nodozităţi şi greutatea plantelor de soia în condiții optime de umiditate. Dar trebuie de menţionat faptul că aceşti cercetători n-au examinat influenţa acestor tulpini rizosferice la plantele crescute la secetă. Datele experimentale prezentului studiu au stabilit că utilizarea îngrăşămintelor organice (gunoiul de grajd) a stimulat mai evident dezvoltarea sistemului simbiotic (faţă de fondul nefertilizat sau fertilizat mineral) şi acest efect benefic s-a depistat şi în condiţii de secetă temporară.

Aşadar, realizarea capacităţii mai bune de creştere şi toleranţă a plantelor de soia la factorii abiotici nefavorabili sub influenţa rizobacteriilor este determinată de îmbunătăţirea condiţiilor de formare a sistemului simbiotic.

\section{Concluzii}

1. Utilizarea microotgnizmelor benefice Bradyrhizobium japonicum și Pseudomonas putida este o strategie de îmbunătăţire a condiţiilor de formare şi dezvoltare a sistemului simbiotic Glycine max-Bradyrhizobium japonicum la plantele de soia atât în condiţii optime de umiditate a solului cât şi în condiţii de secetă de scurtă durată.

2. Aplicarea rizobacteriilor (B. japonicum și $P$. putida) ca secvenţă biotehnologică a îmbunătăţit nutriţia plantelor, a contribuit la formarea unui sistem radicular şi simbiotic mai viguros asigurând o productivitate mai înaltă a plantelor atât în condiții optime de umiditate cât și în condiții de secetă temporară.

3. Efectele pozitive induse de microorganismele benefice au asigurat o mai bună toleranţă a plantelor față de acțiunea secetei de scurtă durată şi disbalans nutritiv cu fosfor, efectele benefice influențând asupra sporirii cantităţii de nodozităţi. Influenţa lor de inducere a creşterii şi toleranţei se manifestă mai evident la plantele de soia cu aplicarea rizobacteriilor pe fondalul fertilizării organice a plantelor, cultivate pe solul de cernoziom carbonatic. 


\section{Bibliografie}

1. Andries S. Regimul fosforului în solurile Moldovei şi eficacitatea îngrăşămintelor cu fosfor. Materialele conferinţei ştiintifice internationale "Creşterea impactului cercetării şi dezvoltării capacității de inovare". Conferinta ştiintifică cu participare internatională consacrată aniversării a 65 a USM. Chisinau USM, 21-22 septembrie 2011, 1:193-196.

2. Alguacil M.M., Kohler J., Caravaca F., Roldán A. Differential effects of Pseudomonas mendocina and Glomus intraradices on lettuce plants physiological response and aquaporin PIP2 gene expression under elevated atmospheric CO2 and drought. Microb Ecol., 2009, 58: 942-951.

3. Egamberdieva D, Kucharova Z. Selection for root colonizing bacteria stimulating wheat growth in saline soils. Biol Fert Soils. 2009, 45:563-571.

4. Egamberdieva D., Reckling M., Wirth S. Biochar-based Bradyrhizobium inoculum improves growth of lupin (Lupinus angustifolius L.) under drought stress. European Journal of Soil Biology, 2017, 78:38-42.

5. Franzini V.I., Rosario A., Fernanda L.M., Aroca R. Different interaction among Glomus and Rhizobium species on Phaseolus vulgaris and Zea mays plant growth, physiology and symbiotic development under moderate drought stress conditions. Plant Growth Regul., 2013, 70:265-273.

6. Hungria M., Nogueira M.A., Araujo R. Soybean seed Coinoculation with Bradyrhizobium spp. and Azospirillum brasilense: a new biotechnological tool to improve yield and sustainability. Am. J. Plant Sci., 2015, 6:811-817.

7. Kunert K.J., Vorster B.J., Fenta B.A., Kibido T., Dionisio G., Foyer C.H. Drought Stress Responses in Soybean Roots and Nodules. Front. Plant Sci., 2016, 7:1015. doi: 10.3389/fpls.2016.01015.

8. Messele B., Pant L.M. Effects of inoculation of Sinorhizobium ciceri and phosphate solubilizing bacteria on nodulation, yield and nitrogen and phosphorus uptake of chickpea (Cicer arietinum L.) in Shoa Robit area. J Biof. Biopest., 2012, 3:129-133. doi:10.4172/21556202.10000129.

9. Nehra V., Choudhary M. A review on plant growth promoting rhizobacteria acting as bioinoculants and their biological approach towards the production of sustainable agriculture. Journal of Applied and Natural Science, 2015, 7(1):540-556.

10. Niu X., Song L., Xiao Y., Ge W. Drought-Tolerant Plant Growth-Promoting Rhizobacteria Associated with Foxtail Millet in a Semi-arid Agroecosystem and Their Potential in Alleviating Drought Stress. Front. Microbiol., 2018. 8:2580. doi: 10.3389/fmicb.2017.02580.

11. Ojuederie O.B., Olanrewaju O.S., Babalola O.O. Plant Growth Promoting Rhizobacterial Mitigation of Drought Stress in Crop Plants: Implications for Sustainable Agriculture. Agronomy 2019, 9, 712; doi:10.3390/agronomy9110712.

12. Polonenko D.R., Scher F.M., Kloepper J.W., Singleton C.A., Laliberte M., Shabayev V.P. Response of legumes to co-inoculation with nodule bacteria and plant growth promoting rhizobacteria. International Journal of Science and Technology, 2015, V. 5, No.9 84-92.

13. Zaidi A., Khan M.S. Interactive effect of rhizospheric microorganisms on growth, yield and nutrient uptake of wheat. J. Plant Nutr., 2005, 28:2079-2092. 